\title{
Pesticide Knowledge and Safety Practices among Farm Workers in Kuwait: Results of a Survey
}

\author{
Mustapha F.A. Jallow *, Dawood G. Awadh, Mohammed S. Albaho, Vimala Y. Devi \\ and Binson M. Thomas
}

Environment and Life Sciences Research Center, Kuwait Institute for Scientific Research, P.O. Box 24885, Safat 13109, Kuwait; dawadh@kisr.edu.kw (D.G.A.); mbahouh@kisr.edu.kw (M.S.A.); ydevi@kisr.edu.kw (V.Y.D.); bmthomas@kisr.edu.kw (B.M.T.)

* Correspondence: mjallow@kisr.edu.kw; Tel.: +965-2498-9843

Academic Editor: Mohamed-Bassem A. Ashour

Received: 5 January 2017; Accepted: 10 March 2017; Published: 24 March 2017

\begin{abstract}
The unsafe and indiscriminate use of pesticides in agriculture represents a major hazard to the environment and human health. The aim of this study was to assess the levels of knowledge, attitude and practices of Kuwaiti farmers regarding the safe use of pesticides. A total of 250 farmers participated in this study through in-depth interviews and observations on-farm. The majority of the farmers acknowledged that pesticides were harmful to their health $(71 \%)$ and the environment $(65 \%)$. However, farmers' level of knowledge of pesticide safety is insufficient. Over $70 \%$ of the farmers did not read or follow pesticide label instructions, and $58 \%$ did not use any personal protective equipment (PPE) when handling pesticides. Educated farmers were significantly more likely to use PPE compared with famers with limited formal education $\left(\chi^{2}=9.89, p<0.05\right)$. Storage of pesticides within living areas was reported by $20 \%$ of farmers. When disposing of pesticide wastes, respondents adopted unsafe practices such as discarding, incinerating, or burying empty pesticide containers on-farm, or reusing the containers. Farmers also reported disposing leftover pesticide solution or old pesticide stocks on-farm or in the sewer. A significant number (82\%) of the farmers reported at least one symptom of acute pesticide poisoning. Although farmers' knowledge of pesticide hazards was high, the reported safety measures were poor. Comprehensive intervention measures to reduce the health and environmental risks of pesticides are needed, including pesticide safety training programs for farmers, stringent enforcement of pesticide laws, and promoting integrated pest management and non-synthetic methods of pest control.
\end{abstract}

Keywords: pesticide exposure; knowledge; risk; health hazards; smallholder farmers

\section{Introduction}

Pesticides have become an integral part of present day farming, and play a major role in increasing agricultural productivity. However, the indiscriminate and extensive use of pesticides represents one of the major environmental and public health problems all over the world [1,2]. If improperly used, pesticides can lead to secondary pest outbreaks [3], destruction of non-target species [4], soil, water, and air contamination [5,6], and residues in primary and derived agricultural products [7] that endanger both the environment and human health. Farm workers' exposure to pesticides has been associated with adverse health effects like cancer and birth defects resulting in hundreds of fatalities, the majority of which occur in developing countries [8,9]. Farmers, and especially those directly involved in the handling of pesticides, are at a high risk of exposure to pesticides through contact with pesticide residues on treated crops, unsafe handling, storage and disposal practices, poor maintenance of spraying equipment, and the lack of protective equipment or failure to use it properly $[8,10]$. 
These risks may be exacerbated by lack of information on pesticide hazards [10], the perception and attitude of farmers regarding risk from pesticide exposure [11], and to lack of education and poor knowledge and understanding of safe practices in pesticide use, including storage, handling and disposal [12]. Higher levels of education gives pesticide users better access to information and more knowledge of the risks associated with pesticides, and how to avoid exposure. While less educated farmers may be hampered in their ability to understand the hazard warnings on pesticide labels, how to avoid exposure, and how to follow recommended safety and application guidelines. For example, illiteracy and lack of knowledge on the extent to which pesticides represent a hazard have been considered the most important barriers for the adoption of self-protective behaviors by farmers, in particular the use of personal protective equipment (PPE) [13,14].

Kuwait has made significant investments in the past four decades towards developing new agricultural strategies, and has created a favorable environment for agricultural expansion to help facilitate at least a modest level of self-sufficiency in food production. Consequently, there is a growing interest in agricultural activities, especially vegetable production in open fields and protected environments for fresh market consumption. The prevalence of the problems caused by insect pests and diseases has resulted in high demand for pesticides in Kuwait [15]. For most farmers, vegetable production, especially in greenhouse environments, is not possible without intensive use of chemical pesticides due to farmers' lack of access to non-synthetic methods of pest control. The annual consumption of pesticides in Kuwait was about 4.5 (kg ai)/ha per year in 2007 [16], and by 2015 this figure has increased to 12.8 ( $\mathrm{kg}$ ai)/ ha per year [17]. This excessive amount of pesticide use does not translate into increased crop yields for the farmers, but rather increases the potential to adversely affect human health and the environment. Pesticide use is further complicated by farmers' not perceiving these chemicals as hazardous or that they have to be handled correctly.

Due to the potential health effects of pesticides, most countries, including Kuwait, have developed laws and regulations to encourage safe pesticide use. For example, Law No. 21 of 2009 and Law No. 42 of 2014, dealing with procedures for the use of pesticides including, registration, sale, distribution, transportation, storage and handling. Similarly, resolution No. 95 of 1995 is concerned with banning the circulation of hazardous pesticides to protect human health and the environment. However, the basic problem lies in the inadequacy of enforcing these laws at the retail and farm level due to the lack of effective enforcement mechanisms. Evidence exists of pesticide-related health effects in Kuwait [18-20]. Pesticide residues have been detected in a number of vegetables in Kuwait [21-24], and the presence of chlorinated pesticides in the breast milk of lactating women has raised even greater concerns about possible health risks to breastfed infants [25].

Research on pesticides in Kuwait has primarily focused on pesticide toxicity, the effects of pesticides on human health and the environment [22,24], and more recently the determinants of pesticide overuse by farmers [17]. Jallow et al. [17] reported that $58 \%$ of smallholder vegetable farmers in Kuwait overused pesticides. Pesticide application frequency ranged from two times a month up to once a week, depending on the crop. In this paper, we focus specifically on the understanding of farmers' knowledge and practices with respect to pesticide safety. Understanding farmers' knowledge of pesticides and safety practices is vital not only for identifying exposure situations and knowledge gaps, but also to provide valuable information that can contribute to educational and policy recommendations aimed at preventing or reducing the health and environmental hazards associated with pesticides. Therefore, the aim of the work described in this paper is to assess the levels of knowledge, attitude and practices of Kuwaiti smallholder farmers regarding the safe use of pesticides. Specifically we aim to:

1. Determine the knowledge and awareness of the farmers regarding pesticides, and their experiences with acute pesticide poisoning in connection with handling pesticides.

2. Assess farmers' practices and attitudes regarding storage, handling and disposal of pesticides.

3. Evaluate the protective measures taken by farmers, including the adoption of PPE, to reduce occupational pesticide exposure. 


\section{Materials and Methods}

\subsection{Questionnaire Development and Delivery}

Diagnostic surveys, formal interviews, and field observations were used to gather information on farmers' knowledge of pesticides and safety practices. Data were collected through face-to-face interviews with 250 farmers (farm managers and their employees directly involved in pesticide use and management), from 200 farms in Kuwait's two major agricultural regions (Wafra and Abdally). Detailed description of the study area, including cropping systems is highlighted in Jallow et al. [17]. The sample size (200 farms) was determined using the Leslie Kish [26] formula to provide a good estimate of the sampled population. Wafra and Abdally regions account for more than $90 \%$ of the total crop production in Kuwait [27]. Cropping systems are mainly based on open field and greenhouse production, with about 30,000 ha under cultivation. Farms of about 5 ha dominate the agricultural landscape, mostly growing dates, vegetables, cereals, pulses, and forages. It is worth noting that the majority of the farms, although owned by Kuwaitis, are typically operated and managed by predominantly expatriate laborers from North Africa and the Indian subcontinent who also constitute the majority of the agricultural labor force in Kuwait [27]. Multistage-sampling was used for the purpose of the survey. Each region was divided into four clusters, and within each cluster individual farms were selected by random sampling using an automatic random number generator. In all, 120 farms from Abdally and 80 farms from Wafra were selected for the survey.

A questionnaire was designed in English and translated into Arabic, the national language that is understood by majority of the farmers, and was administered either in Arabic or English on-farm. The questionnaire included closed and open-ended questions, and was pre-tested by randomly interviewing twenty farmers not included in this study. The closed questions were in a multiple choice format so that respondents had to select only the appropriate answer or answers that they thought best described their opinion or attitude on a particular issue. The questionnaire contained three main sections. The first section was designed to collect information on personal characteristics of the farmers including age, educational level, and years of farming experience. The second section focused on collecting information on farmers' level of awareness of pesticide laws and regulations, and knowledge and understanding of pesticides with respect to the environmental and human health. In addition, we also collected data on self-reported toxicity symptoms associated with pesticide use, as well as farmers' knowledge about exposure routes. When symptoms were assessed, respondents were asked if within the past year prior to the date of the interview they experienced at least one heath impairment immediately after applying or handling pesticides. If the answer was yes, respondents were asked to specify which symptoms they had experienced. The third section included questions regarding pesticide handling and safety practices including reading and following label instructions, storing and disposing of pesticides and empty containers, and use of PPE and other protective practices during and after pesticide application.

\subsection{Data Analysis}

All data were coded, entered, and then analyzed using SPSS version 20 (SPSS Inc., Chicago, IL, USA) and Microsoft Office Excel 2010 (Microsoft Corporation, Redmond, WA, USA). Descriptive results were expressed as frequencies and percentages, and the Chi-square test $\left(\chi^{2}\right)$ was used to measure the possible association between nominal variables [28]. We used $\alpha \leq 0.05$ as a criterion for statistical significance.

\section{Results}

\subsection{Demographic Characteristics and Profile of the Farmers}

All farmers surveyed in the study were men, as farming activities especially those related to pesticide use are performed exclusively by men in Kuwait. The majority of the farmers (69.70\%) 
interviewed were between 21 and 40 years old, with the average age being 29.8 years. Slightly more than $9 \%$ of the farmers were 50 years and over. A considerable number of the farmers $(16.8 \%)$ were illiterate or had not completed elementary education, $69.2 \%$ had completed either elementary or secondary education, and $14 \%$ were educated to a tertiary level. The majority of the farmers educated to the tertiary level were expert agronomists $(71.4 \%)$, and $22.9 \%$ had received training in pest management. Most of the respondents (68\%) had 5-10 years of farming experience, with $10.4 \%$ having more than 10 years of farming experience. Farm sizes varied from less than 5 ha to over 10 ha, with an average of 4.5 ha.

\subsection{Pesticides Used}

A total of 76 pesticide active ingredients were found to be in use during the survey period (Table 1 ). About 47\% (35 out of 76) of the pesticides used belonged to the World Health Organization (WHO) toxicity class II (moderately hazardous), with a few (9\%) under toxicity class Ib (highly hazardous). WHO toxicity class II pesticides (moderately hazardous) were used by $90 \%$ of the farmers, followed by class III (slightly hazardous) $68 \%$. Slightly more than $12 \%$ of the farmers used class Ib pesticides (highly hazardous), including monocrotophos, oxamyl, abamectin, beta-cyflurthrin, methomyl, fenamiphos, triazophos, and fenamiphos. Insecticides were used by $98 \%$ of the farmers, followed by fungicides and bactericides $(79 \%)$, nematicides $(24 \%)$ and herbicides $(5 \%)$.

Table 1. Classification of pesticides used by farmers and their toxicological class.

\begin{tabular}{|c|c|c|}
\hline Active Ingredient & WHO Toxicity Class ${ }^{a}$ & Classification by Main Group \\
\hline Primiphos methyl & II & Organophosphate \\
\hline Diazinon & II & Organophosphate \\
\hline Acephate & II & Organophosphate \\
\hline Monocrotophos & $\mathrm{Ib}$ & Organophosphate \\
\hline Malathion & III & Organophosphate \\
\hline Profenofos & II & Organophosphate \\
\hline Trichlorfon & II & Organophosphate \\
\hline Dimethoate & II & Organophosphate \\
\hline Dimethoate & II & Organophosphate \\
\hline Fenvalerate & II & Pyrethroid \\
\hline Lambda-cyhalothrin & II & Pyrethroid \\
\hline Permethrin & II & Pyrethroid \\
\hline Cypermethrin & II & Pyrethroid \\
\hline Beta-cyfluthrin & $\mathrm{Ib}$ & Pyrethroid \\
\hline Etofenprox & III & Pyrethroid \\
\hline Fenpropathrin & II & Pyrethroid \\
\hline Deltamethrin & II & Pyrethroid \\
\hline Bifenthrin & II & Pyrethroid \\
\hline Alpha-cypermethrin & II & Pyrethroid \\
\hline Benfuracarb & II & Carbamate \\
\hline Methomyl & $\mathrm{Ib}$ & Carbamate \\
\hline Oxamyl & $\mathrm{Ib}$ & Carbamate \\
\hline Acetamiprid & II & Neonicotinoid \\
\hline Thiacloprid & II & Neonicotinoid \\
\hline Imidacloprid & II & Neonicotinoid \\
\hline Spirotetramat derivative & III & Tetramic acid \\
\hline Dinobuton & II & Dinitrophenol derivative \\
\hline Spinosad & III & Spinosyns \\
\hline Abamectin & $\mathrm{Ib}$ & Avermectin \\
\hline Fenpyroximate & II & Fenpyroximate \\
\hline Cyromazine & III & Cyromazine \\
\hline Bifenazate & $\mathrm{U}$ & Bifenazate \\
\hline Thiocyclam hydrogen oxalate & II & Nereistoxin \\
\hline Bromopropylate & NC & Bromopropylate \\
\hline
\end{tabular}


Table 1. Cont.

\begin{tabular}{|c|c|c|}
\hline Active Ingredient & WHO Toxicity Class ${ }^{a}$ & Classification by Main Group \\
\hline Amitraz & II & Amitraz \\
\hline Cartap hydrochloride & II & Nereistoxin \\
\hline Flufenoxuron & III & Benzoylurea \\
\hline Fipronil & II & Phenylpyrazole \\
\hline Buprofezin & III & Buprofezin \\
\hline Chlorfenapyr & II & Chlorfenapyr \\
\hline Pyriproxyfen & $\mathrm{U}$ & Pyriproxyfen \\
\hline Azoxystrobine & $\mathrm{U}$ & Fungicide and bactericides \\
\hline Difenoconazole & II & Fungicide and bactericides \\
\hline Mefenoxam & $\mathrm{NC}$ & Fungicide and bactericides \\
\hline Triphenyltin hydroxide & $\mathrm{U}$ & Fungicide and bactericides \\
\hline Propamocarb hydroxide & $\mathrm{U}$ & Fungicide and bactericides \\
\hline Benomyl & $\mathrm{U}$ & Fungicide and bactericides \\
\hline Dazomet & II & Fungicide and bactericides \\
\hline Tebuconazole & II & Fungicide and bactericides \\
\hline Hymexazol & III & Fungicide and bactericides \\
\hline Tolclofos-methyl & $\mathrm{U}$ & Fungicide and bactericides \\
\hline Maneb & Us & Fungicide and bactericide \\
\hline Cuprous oxide & II & Fungicide and bactericides \\
\hline Fenhexamid & $\mathrm{U}$ & Fungicide and bactericides \\
\hline Mancozeb & $\mathrm{U}$ & Fungicide and bactericides \\
\hline Copper hydroxide & II & Fungicide and bactericides \\
\hline Copper oxychloride & II & Fungicide and bactericides \\
\hline Thiophanate-methyl & $\mathrm{U}$ & Fungicide and bactericides \\
\hline Dinocap & II & Fungicide and bactericides \\
\hline Propamocarb & $\mathrm{U}$ & Fungicide and bactericides \\
\hline Metalaxyl & II & Fungicide and bactericides \\
\hline Fenamiphos & $\mathrm{Ib}$ & Nematicides \\
\hline Metam-sodium & II & Nematicides \\
\hline Oxamyl & $\mathrm{Ib}$ & Nematicides \\
\hline Benomyl & $\mathrm{U}$ & Nematicides \\
\hline Triazophos & $\mathrm{Ib}$ & Nematicides \\
\hline Carbosulfan & II & Nematicides \\
\hline Diamidafos & $\mathrm{NC}$ & Nematicides \\
\hline Fenamiphos & $\mathrm{Ib}$ & Nematicides \\
\hline Thionazin & $\mathrm{NC}$ & Nematicides \\
\hline Fensulfothion & $\mathrm{NC}$ & Nematicides \\
\hline Dichlofenthion & $\mathrm{NC}$ & Nematicides \\
\hline Pendimethalin & II & Herbicides \\
\hline Glyphosate & III & Herbicides \\
\hline Oxadiazon & $\mathrm{U}$ & Herbicides \\
\hline Metolachor & III & Herbicides \\
\hline Sethoxydim & III & Herbicides \\
\hline
\end{tabular}

a Ib: Highly hazardous; II: Moderately hazardous; III: Slightly hazardous; U: Unlikely to pose an acute hazard in normal use; NC: Not classified.

\subsection{Farmers' Knowledge, Attitude, and Understanding about Pesticides}

The farmers' level of knowledge of pesticides, including exposure routes, effects on the environment and human health, and their awareness of pesticide laws and regulations was analyzed in Table 2. The majority (64\%) of the farmers had not received any training or technical support on the judicious use and safe handling of pesticides, while $36 \%$ were trained. Although most farmers agreed that pesticide use poses some risk to human health $(71 \%)$ and the environment $(65 \%)$, they also indicated that pesticides were indispensable for high crop yield (80\%). Over $70 \%$ of the farmers did not read or follow instructions on pesticide labels, because they were unable to read and understand the meaning of the labels (56\%), the labels were written in English (a foreign language to them) (35\%), and 
the instructions were too long and complicated (45\%). Slightly more than $15 \%$ of the farmers indicated that font sizes on the labels were too small to easily read. Only $28 \%$ of the farmers were able to read, understand, and follow pesticide label instructions correctly.

Table 2. Farmers' knowledge, attitude and understanding about pesticide $(n=250)$.

\begin{tabular}{|c|c|c|c|}
\hline Question & Variable & $\mathbf{n}$ & $\%$ \\
\hline \multicolumn{4}{|c|}{ Do you think that pesticides affect human health? } \\
\hline & Strongly agree & 120 & 48 \\
\hline & Agree & 57 & 23 \\
\hline & Disagree & 60 & 24 \\
\hline & Strongly disagree & 13 & 5 \\
\hline \multicolumn{4}{|c|}{ Do you think that pesticides affect the environment? } \\
\hline & Strongly agree & 98 & 39 \\
\hline & Agree & 65 & 26 \\
\hline & Disagree & 60 & 24 \\
\hline & Strongly disagree & 27 & 11 \\
\hline \multicolumn{4}{|c|}{ Do you think pesticides are indispensable for high crop yield? } \\
\hline & Strongly agree & 155 & 62 \\
\hline & Agree & 45 & 18 \\
\hline & Disagree & 36 & 14 \\
\hline & Strongly disagree & 14 & 6 \\
\hline \multicolumn{4}{|c|}{ Do you read, understand and follow pesticide labels? } \\
\hline & Yes & 70 & 28 \\
\hline & No & 180 & 7 \\
\hline \multicolumn{4}{|c|}{ How do pesticides enter the human body? ${ }^{a}$} \\
\hline & Dermal & 135 & 54 \\
\hline & Inhalation & 215 & 86 \\
\hline & Oral & 105 & 42 \\
\hline & Eye contact & 65 & 26 \\
\hline & Don't know & 35 & 14 \\
\hline \multicolumn{4}{|c|}{ Do you know some pesticides are banned or restricted for use? } \\
\hline & Yes & 145 & 58 \\
\hline & No & 105 & 42 \\
\hline \multicolumn{4}{|c|}{ Do you know the pesticides that are banned or restricted for use? } \\
\hline & Yes & 29 & 20 \\
\hline & No & 116 & 80 \\
\hline \multicolumn{4}{|c|}{ Do you know the reasons for banning or restricting pesticides? ${ }^{a, b}$} \\
\hline & Highly toxic & 84 & 58 \\
\hline & Not effective & 115 & 79 \\
\hline & Expensive & 41 & 28 \\
\hline & Dont't know & 30 & 21 \\
\hline
\end{tabular}

a Multiple responses allowed; ${ }^{\mathrm{b}}$ Percentage of respondents who knew that pesticides are banned or restricted for use $(\mathrm{n}=145)$.

When farmers were asked to indicate how pesticides enter the human body, dermal (54\%), inhalation $(86 \%)$, and oral $(42 \%)$ were stated as the most common routes of exposure to pesticides. About $14 \%$ of the farmers indicated lack of knowledge of any route of exposure to pesticides. The majority of the farmers ( $58 \%$ ) are aware that some pesticides have been banned or are restricted for use. However, among this group, only $20 \%$ of the farmers knew the names of some the pesticides that are banned or restricted for use. Examples include dichloro-diphenyl-trichloroethane (DDT), permethrin, methiocarb, and methamidophos, all of which are highly hazardous to human health and 
the environment. Among farmers who are aware that some pesticides have been banned or restricted for use, the high toxicity of the pesticides (58\%), not effective $(79 \%)$ and expensive $(28 \%)$ were cited as major reasons for the ban or restriction.

\subsection{Farmers' Practices on Storage and Disposal of Pesticides}

Farmers' attitudes towards storing of pesticides and disposal of residual pesticide solutions, expired pesticides, and empty pesticide containers are shown in Table 3. The majority of the farmers $(59 \%)$ stored their pesticides in locked chemical stores designated only for pesticides. Respondents also stored their pesticides in open sheds just for pesticides $(34 \%)$ and in the open field $(30 \%)$. A worrying $15 \%$ of the farmers reported storing pesticides in an animal house, in a refrigerator with other items $(8 \%)$, or within their living area $(20 \%)$. Respondents with higher education levels were significantly less likely to store pesticides in their home $\left(\chi^{2}=20.89, p<0.01\right)$. When asked what they do with residual pesticide solutions, $82 \%$ of respondents reported that they apply the leftover solution on other crops, disposed the solution in the field $(35 \%)$, in the sewer $(4 \%)$ or deliver the solution to the municipality hazardous waste collection sites for disposal (23\%). Only $18 \%$ of respondents reported mixing only the amount of pesticides that is needed for the application at hand.

Table 3. Farmers' practices on storage and disposal of pesticides $(n=250)$.

\begin{tabular}{|c|c|c|c|}
\hline Question & Variable & $\mathrm{n}^{\mathrm{a}}$ & $\%$ \\
\hline \multicolumn{4}{|c|}{ Where do you store pesticides? } \\
\hline & Open shed just for pesticides & 86 & 34 \\
\hline & Refrigerator, with other items & 20 & 8 \\
\hline & In the open field & 76 & 30 \\
\hline & Locked chemical store & 148 & 59 \\
\hline & Living area & 50 & 20 \\
\hline & Animal house & 38 & 15 \\
\hline \multicolumn{4}{|c|}{ What do you do with the unused leftover (mixed, diluted) pesticides? } \\
\hline & Dispose in the field & 87 & 35 \\
\hline & Mix only needed pesticides & 45 & 18 \\
\hline & Apply on other crops & 205 & 82 \\
\hline & Dispose in sewer & 10 & 4 \\
\hline & Hazardous waste collection sites & 57 & 23 \\
\hline \multicolumn{4}{|c|}{ What do you do with old pesticides stocks? } \\
\hline & Return to retailer & 12 & 5 \\
\hline & Hazardous waste collection sites & 40 & 16 \\
\hline & Dispose in the field & 68 & 27 \\
\hline & Buy only amount needed & 155 & 62 \\
\hline & Dispose in sewer & 7 & 3 \\
\hline \multicolumn{4}{|c|}{ What do you do with empty pesticide containers? } \\
\hline & Discard on-farm & 67 & 27 \\
\hline & Place in trash or dumpster & 125 & 50 \\
\hline & Incinerate on-farm & 108 & 43 \\
\hline & Hazardous waste collection sites & 98 & 39 \\
\hline & Bury on-farm & 63 & 25 \\
\hline & Reuse for other purposes & 15 & 6 \\
\hline
\end{tabular}

${ }^{\text {a }}$ Multiple responses allowed.

Disposal of old pesticide stocks is often done by delivering them to the municipality hazardous waste collection sites $(16 \%)$, disposing in open fields $(27 \%)$, in the sewer $(3 \%)$ or returning the obsolete pesticide to pesticide retailers (5\%). Over $60 \%$ of the farmers claimed that they buy only the amount of pesticides they need. The common way of disposing of empty pesticide containers was placing 
them in garbage containers and/or dumpsters for disposal at the landfill (50\%), incinerating them on the farm $(43 \%)$, or delivering them to the municipality hazardous waste collection sites for disposal $(39 \%)$. Respondents (25\%) also buried the containers on-farm or discarded them on the farm $(27 \%)$. Alarmingly, $6 \%$ of the farmers reported re-using empty pesticide containers for household purposes. A significant association $\left(\chi^{2}=8.98, p<0.05\right)$ was observed between years of farming experience and safe pesticide storage and disposal.

\subsection{Farmers' Safety Practices against Occupational Exposure to Pesticides}

Protective measures during and after pesticide application are important to reduce exposure to pesticides. The majority ( $58 \%$ ) of the farmers did not use any PPE when mixing or spraying pesticides (Table 4). When respondents were asked to indicate the main reasons for not using PPE, lack of availability when needed (35\%), and PPE being uncomfortable in the local hot and humid climate $(90 \%)$, too expensive $(65 \%)$, and slowing you down $(29 \%)$ were the most reasons cited. Respondents $(6 \%)$ also cited not experiencing any health problems from using pesticides as reason for not using PPE. Among respondents who reported using PPE, less that $5 \%$ wore all the recommended six key PPE items (coveralls, protective boots, glasses/goggles, gloves, respirator, and hat). The PPE most often used were protective gloves $(61 \%)$, hats $(42 \%)$, and glasses/goggles $(48 \%)$. A significant number of respondents reported not wearing respirators $(70 \%)$, coveralls $(68 \%)$, or protective boots $(54 \%)$ at all. Younger and educated farmers were more likely to use PPE compared with older farmers or famers with limited formal education $\left(\chi^{2}=9.89, p<0.05\right)$. However, no association was observed between farming experience and use of PPE.

Table 4. Farmers' reported use of personal protected equipment when mixing and spraying pesticides to prevent occupational pesticide exposure $(n=150)^{\text {a }}$.

\begin{tabular}{cccc}
\hline Protective Equipment & Variable & $\mathbf{n}$ & $\mathbf{( \% )}$ \\
\hline \multirow{3}{*}{ Coveralls } & Always & 19 & 18 \\
& Sometimes & 15 & 14 \\
& Never & 71 & 68 \\
\hline \multirow{3}{*}{ Protective boots } & Always & 20 & 19 \\
& Sometimes & 28 & 27 \\
& Never & 57 & 54 \\
\hline \multirow{3}{*}{ Glasses/goggles } & Always & 50 & 48 \\
& Sometimes & 23 & 22 \\
& Never & 32 & 30 \\
\hline \multirow{3}{*}{ Gloves } & Always & 64 & 61 \\
& Sometimes & 38 & 36 \\
& Never & 3 & 3 \\
\hline \multirow{2}{*}{ Respirator } & Always & 4 & 4 \\
& Sometimes & 27 & 26 \\
& Never & 74 & 70 \\
\hline \multirow{2}{*}{ Hat } & Always & 44 & 42 \\
& Sometimes & 54 & 51 \\
\hline
\end{tabular}

a Number of respondents who wore at least one personal protective equipment during mixing and spraying pesticides.

Apart from PPE use, farmers were asked if they implement other safety measures to reduce their risk of exposure to pesticides. The majority of respondents reported not eating (72\%), drinking $(65 \%)$ or smoking (59\%) when mixing or applying pesticides (Table 5). Furthermore, $82 \%$ of respondents reported taking a shower immediately after mixing or spraying pesticides. Over $70 \%$ of respondents, however, did not wash work clothing used while mixing or spraying pesticides separately from 
other cloths. Similarly, $46 \%$ of respondents reported that they did not consider wind direction when spraying pesticides.

Table 5. Farmers' reported safety practices other than wearing personal protected equipment to prevent occupational pesticide exposure $(n=250)$.

\begin{tabular}{cccc}
\hline Protective Equipment & Variable & $\mathbf{n}$ & $\mathbf{\%}$ \\
\hline \multirow{3}{*}{ Eating while mixing or spraying } & Always & 0 & 0 \\
& Sometimes & 70 & 28 \\
& Never & 180 & 72 \\
\hline \multirow{3}{*}{ Drinking while mixing or spraying } & Always & 0 & 0 \\
& Sometimes & 88 & 35 \\
& Never & 162 & 65 \\
\hline \multirow{3}{*}{ Smoking while mixing or spraying } & Always & 4 & 2 \\
& Sometimes & 98 & 39 \\
& Never & 148 & 59 \\
\hline \multirow{3}{*}{ Sprayed with the wind direction } & Always & 45 & 18 \\
& Sometimes & 90 & 36 \\
& Never & 115 & 46 \\
\hline \multirow{2}{*}{ Showering immediately after } & Always & 205 & 82 \\
mixing or spraying & Sometimes & 12 & 5 \\
& Never & 33 & 13 \\
\hline \multirow{2}{*}{ Wash work clothes separately } & Always & 45 & 18 \\
& Sometimes & 21 & 8 \\
& Never & 184 & 74 \\
\hline
\end{tabular}

\subsection{Self-Reported Toxicity Symptoms Related to Pesticides}

A significant number ( $82 \%$ ) of the farmers reported at least one symptom of acute pesticide poisoning in the previous year immediately after applying or handling pesticides, while $18 \%$ of respondents did not ascribe any health problem encountered to pesticide exposure (Table 6). The most frequently reported symptoms were headaches (82\%), skin irritation (58\%), nausea (49\%), itchy eyes $(79 \%)$, dizziness $(41 \%)$, fatigue $(50 \%)$, and coughing $(22 \%)$. Other symptoms reported by respondents were poor vision, stomach ache, excessive sweating, shortness of breath, and vomiting. When respondents were asked what action they took following an incident of poisoning, a majority $(75 \%)$ reported taking no action as the incident was minor or required only self-medication. Only $5 \%$ of respondents reported a serious poisoning incident that required medical attention in a hospital.

Table 6. Problems reported by farmers after mixing or spraying pesticides $(n=250)^{a}$.

\begin{tabular}{ccc}
\hline Symptoms & $\mathbf{n}^{\mathbf{b}}$ & $\mathbf{\%}$ \\
\hline Headaches & 205 & 82 \\
Dizziness & 102 & 41 \\
Skin irritation & 145 & 58 \\
Nausea & 122 & 49 \\
Itchy eyes & 198 & 79 \\
Vomiting & 25 & 10 \\
Coughing & 54 & 22 \\
Shortness of breath & 19 & 8 \\
Excessive sweating & 25 & 10 \\
Fatigue & 125 & 50 \\
Stomach ache & 10 & 4 \\
Poor vision & 6 & 3 \\
No health impairment & 45 & 18 \\
\hline
\end{tabular}

a Respondents were asked if within the past year prior to the date of the interview they experienced at least one heath impairment immediately after applying or handling pesticides; ${ }^{\mathrm{b}}$ Multiple responses allowed. 


\section{Discussion}

Understanding farmers' level of knowledge and practices regarding the safe use of pesticides is vital for providing sound educational and policy strategies that aim at limiting the health and environmental hazards caused by pesticides. The majority of farmers in this study were well aware of the harmful effects of pesticides with regard to the environment and human health, but contrary to expectations, this did not significantly change their practices or attitudes towards safe pesticide use. This suggests that even though farmers may know the hazards of pesticides very well, they may often adopt risky behaviors because of lack of education and poor knowledge and understanding of safe practices in pesticide use [10], or they are more concerned with high economic returns from their crops than with their own health [29]. A considerable number of the respondents in this study were illiterate or had limited formal education, and did not receive any training or technical support in pesticide safety. Consequently, these farmers are hampered in their ability to read and understand pesticide labels regarding the correct and safe use of pesticides, or written communication about how to avoid the risks of exposure [30]. The fact that the majority of the farmers $(72 \%)$ indicated that they did not read or follow pesticide labels (Table 2) is a great cause for concern, and perhaps indicates a general ignorance of the importance of pesticide labels in reducing exposure risk. Educated farmers are more knowledgeable about pesticide safety, have better ability to read, understand and follow hazard warnings on labels, and conceptualized the consequences of poor pesticide usage practices [12]. Even when able to read, some respondents in this study acknowledged they were reluctant to read pesticide labels because of their experience with pesticide use.

Our study showed some worrying practices about storage of pesticides, with $20 \%$ of the farmers storing pesticides in living areas or in refrigerators ( $8 \%$ ) with other items (Table 3). This demonstrates the farmers' lack of knowledge of pesticides and the appropriate approach for storing pesticides. Storing pesticides in living areas can increase the potential for high exposure, especially when these areas are the places where farmers prepare food, eat, and sleep. Farmers also stored pesticides in animal housing that could pose a danger to farm animals (Table 3). Unfortunately, storing of pesticides in residences and in the open is prevalent in many developing countries. Matthews [10] reported that $27 \%$ of 8500 smallholder farmers in 26 countries stored pesticides in the home or in open areas, and nearly half indicated that they rarely or never locked pesticides away. These risky behaviors can be attributed to farmers' lack of technical knowledge and training on safe pesticide use. Educated farmers and farmers who have access to training on pesticide use are more likely to store pesticides in locked stores designated for pesticides [31]. Likewise, they are more likely to be aware of pesticide-related adverse health and environmental effects [32].

Farmers in this study generally demonstrated a poor knowledge of pesticide disposal, and more than $80 \%$ of respondents re-spray treated areas with leftover pesticide solutions. Leftover pesticide solutions or old pesticide stock were also disposed of in the field or in the sewer (Table 3). These poor pesticide handling practices can lead to harmful residues in harvested produce, and soil and water contamination, posing a threat to both human and environmental health [11]. Some respondents reported that they only mixed the amount of pesticides needed or they deliver leftover solutions to hazardous waste collection sites for disposal, both good options for reducing the hazards of pesticides (Table 3). Unfortunately, these farmers represented less than $25 \%$ of all farmers interviewed in this study. Unsafe disposal of pesticide containers may be an important source of pesticide exposure [31]. When disposing of empty pesticide containers, the majority of respondents adopted unsafe behaviors such as discarding, incinerating or burying containers on-farm. These practices may lead to environmental contamination and a risk to human health, and have been reported as a major problem in a number of studies $[10,33]$. About $5 \%$ of the farmers indicated that they reuse the empty pesticide containers for household purposes, increasing their chances of exposure to pesticides. Respondents emphasize that they always wash the empty pesticide containers before reuse, and they reinforce this by saying that there is no exposure risk because they do not smell the pesticides. Evidence of farmers' reuse of empty pesticide containers has been reported in other studies [34]. 
Use of appropriate PPE, such as coveralls, and the adoption of other protective measures and good personal hygiene such as showering, not smoking, eating or drinking while handling pesticides are considered good practices to reduce occupational pesticide exposure [10]. An increase in the use of protective measures decreases the probability of poisoning by $44 \%$ to $80 \%$ [35], whereas lack of PPE use increases the potential for dermal and respiratory exposure to pesticides [36]. An important finding in this study is that there are low levels of adoption of protective behaviors to reduce occupational exposure to pesticides. The majority of farmers fail to use any PPE, while fewer than $5 \%$ use all the recommended equipment (Table 4). The main reason mentioned for not using PPE was the discomfort under hot and humid conditions, as the environment in Kuwait is characterized by high ambient temperatures, with summer temperatures exceeding $45^{\circ} \mathrm{C}$ [37]. This indicates that farmers may be more willing to risk exposure to pesticides than to use PPE under such climatic conditions [38]. Lack of PPE use is made worse by some farmers not spraying according to the wind direction, and drink, eat and smoke when handling pesticides, all of which increase the danger of poisoning [10]. Similarly, they sprayed more often than required, up to once a week depending on the crop, using pesticides highly hazardous to human health and the environment [27]. Education status and training in pesticide use and safety are strong determinants of the appropriate use of PPE. For example, the perception that PPE were useful to prevent exposure to pesticides was associated with at least a high school education among migrant farm workers in USA [39], farmers in India [40] and in Mexico [14].

Findings in this study will enable government and regulatory agencies to make better-informed decisions and policy recommendations aimed at preventing or reducing the health and environmental hazards associated with pesticides. The knowledge gaps identified in this study could also be used to designed knowledge-based training programs for farmers. Participation in training programs leads to increased levels of knowledge about safety precautions while handling pesticides [29,41]. It is imperative that proper training programs on pesticide safety and on the hazards of pesticide exposure be developed to address gaps in farmers' knowledge about pesticides. The national agricultural extension service should play a pivotal role in the training of farmers, and the information they provide should be up-to-date, accurate, and easy to understand to inspire confidence and trust among the farmers. Farmers' source of information and the degree to which they trust the informants may shape their perceptions of risk of pesticides and the adoption of preventative measures [42]. Our study pointed to significant illiteracy rates among farmers, and this represents a challenge in the design of appropriate training programs. Given that most farmers are unable to read and write, a more interactive and participatory training model is required, for example, by using pictograms to simplify pesticide labels and communicate risk information. The pictograms should be unambiguous and easy to understand, to prevent misinterpretations of the risk information. Using pictograms is seen as a key element for overcoming literacy challenges in transmitting pesticide risk information [43]. Knowledge of the farmers can further be reinforced through field demonstrations. Such capacity-enhancement activities will provide farmers the opportunity to learn and understand how to handle pesticide safely, and how to adopt preventative measures to reduce the risk against occupational exposure. It is also important to educate farmers about alternative cropping systems that are less dependent on pesticides, while at the same time promoting integrated pest management practices.

Pesticide retailers play a critical role in the dissemination of agricultural information to farmers, and farmers in Kuwait rely on them as the primary information and knowledge source on pesticides [17]. Retailers can downplay environment and health effects of pesticides when dealing with farmers for greater profit-making [44], or may be constrained by the lack of knowledge of pesticides [45]. Therefore, training pesticide retailers to increase their knowledge of pesticide safety and risk communication is critical. Retailers should have, at minimum, a technical advisor with competence in the handling of pesticides and knowledge of their hazards to appropriately advise farmers and other end-users. Lack of training of pesticide retailers, who may serve as advisors to farmers and other end-users, has been considered a key factor contributing to occupation exposure to pesticides [46]. Promoting safe pesticide use will also require educating farmers and pesticide retailers 
about the pesticide regulatory framework in Kuwait, and the obligations currently in place. Some farmers lack any knowledge of the pesticide regulatory framework, and were completely unaware that some pesticides are banned or restricted for use because of their toxicity (Table 2). This lack of knowledge is likely to contribute to increased risk to the farmers.

Training farmers alone may not be sufficient to reduce the risk posed by pesticides. Interventions that provide farmers with information and knowledge of pesticide safety should be complemented with other strategies. Greater priority must be given to enforcing existing pesticide laws and regulations at the retail and at the farm level, through surveillance and monitoring activities. Ideally, there should be a pesticide safety certification program for pesticide applicators and retailers to ensure that only those certified are allowed to sell, handle, or apply pesticides. It is also critical to raise awareness among the general public, who may be directly or indirectly be exposed to pesticides, about the risk of these chemicals. Risks to the general public may include inadvertent dermal and inhalation exposure from sprayed fields, contact with treated crops during farm visits, or through harmful residues in primary and derived agricultural products [47].

A limitation of a study such as this is that it is based mainly on self-reported data, relying on the honesty of respondents which is subjected to bias [48]. As a self-report, it is possible that there may be some inaccurate data such as respondents wanting to report socially desirable behaviors. For example, self-report of PPE use and safe disposal of empty pesticide containers, and the adoption of other safety practices may be influenced by the respondents' desire to indicate that they comply with protective measures against occupational pesticide exposure. However in some farms, observations were conducted to verify farmer reports, and we often observed farmers discarding empty pesticide containers or incinerating them on-farm. These observations were supported by the responses of the interviewed farmers. Another limitation relates to the inability to directly link health symptoms experienced by respondents to pesticide exposure. The health symptoms experienced by respondents, such as headaches and fatigue, were not specific, and in some of the cases these symptoms might have been due to causes other than exposure to pesticides, such as long exposure to the sun, especially if no head protection is worn. Nevertheless, that the symptoms reported by respondents occurred immediately after applying or handling pesticides and the frequency of occurrence is a great cause of concern. Finally, based on the number of respondents (250 farmers), we cannot claim that the results are representative for all Kuwaiti farmers. It was not feasible to interview all farmers in Kuwait. However, our intention is not to generalize, but to explore and highlight important occupational health and pesticide safety issues for individual farmers. Furthermore, our findings and previous studies on pesticide poisoning conducted in Kuwait [18-20] all pointed to unsafe pesticide handling practices among farmers. Despite its limitation, this study provides an overview of pesticide safety knowledge and practices among farmers in Kuwait, and can contribute to educational and policy recommendations that aim at preventing or reducing the hazards associated with pesticides. The results may be relevant in other countries where greater and widespread use of pesticides among smallholder farmers is a dominant trend.

\section{Conclusions}

The adverse effects of pesticides have been widely documented. However, awareness among farmers and other applicators of the importance of protecting themselves and the environment from hazards associated with handling pesticides is still lacking. This study investigated the levels of knowledge and practices of Kuwaiti smallholder vegetable farmers regarding the safe use of pesticides. Our study reveal farmers lack adequate knowledge of pesticides, and often adopt risky behaviors when handling pesticides. Knowledge deficits included the poor use of PPE and other safety measures, and the improper storage and disposal of pesticides. To increase farmers' knowledge about pesticide and limit the hazards associated with pesticides, it is recommended that priority is given to developing and implementing pesticide safety educational and certification programs for farmers. Where provided, the training must address health effects associated with exposure to pesticides, the effects of pesticides 
on the environment, improvements in disposal and storage of pesticides, pesticide risk reduction strategies, and understanding of the pesticide regulatory framework in Kuwait. Training pesticide retailers to increase their knowledge of pesticides is also critical, since they are farmers' primary source of information about pesticides. Finally, intervention strategies by regulatory agencies to strengthen enforcement mechanisms of current pesticide laws, through regular surveillance and monitoring pesticide safety compliance at the retail and farm level is a necessity in promoting safe pesticide use. In addition, the importation, sale and the use of highly hazardous pesticides should be restricted.

Acknowledgments: This study was financed by the Kuwait Institute for Scientific Research (FA117K). The contribution of the farmers and the staff of the Kuwait Public Authority for Agriculture and Fish Resources to this study is gratefully acknowledged.

Author Contributions: Mustapha F.A. Jallow conceived and designed the study, developed the questionnaire, analyzed the data, and wrote the manuscript. Dawood G. Awadh, Binson M. Thomas, and Vimala Y. Devi were responsible for data collection, data entry, and administrative support. Mohammed S. Albaho participated in all parts of the work. All authors have read, reviewed and approved the final manuscript before submission.

Conflicts of Interest: The authors declare no conflict of interest. The founding sponsor had no role in the design of the study; in the collection, analyses, or interpretation of data; in the writing of the manuscript, and in the decision to publish the results.

\section{References}

1. Jeyaratnam, J. Acute pesticide poisoning: A major global health problem. World Health Stat. Q. 1990, 43, 139-144. [PubMed]

2. Pimentel, D. Environmental and economic cost of the application of pesticides primarily in the United States. Environ. Dev. Sustain. 2005, 7, 229-252. [CrossRef]

3. Gross, K.; Rosenheim, J.A. Quantifying secondary pest outbreaks in cotton and their monetary cost with causal inference statistics. Ecol. Appl. 2011, 21, 2770-2780. [CrossRef] [PubMed]

4. Andrea, M.M.; Peres, T.B.; Luchini, L.C.; Pettinelli, J.A. Impact of long-term pesticide application on some soil biological parameters. J. Environ. Sci. Health B 2000, 35, 297-307. [CrossRef] [PubMed]

5. Arias-Estévez, M.; López-Periago, E.; Martínez-Carballo, E.; Simal-Gándara, J.; Mejuto, J.C.; García-Río, L. The mobility and degradation of pesticides in soils and the pollution of groundwater resources. Agric. Ecosyst. Environ. 2008, 123, 247-260. [CrossRef]

6. Bedos, C.; Cellier, P.; Calvet, R.; Barriuso, E.; Gabrielle, B. Mass transfer of pesticides into the atmosphere by volatilization from soils and plants: Overview. Agronomie 2002, 22, 21-33. [CrossRef]

7. Osman, K.A.; Al-Humaid, A.M.; Al-Redhaiman, K.N. Monitoring of pesticide residues in vegetables marketed in Al-Qassim region, Saudi Arabia. Ecotox. Environ. Saf. 2010, 73, 1433-1439. [CrossRef] [PubMed]

8. Litchfield, M.H. Estimates of acute pesticide poisoning in agricultural workers in less developed countries. Toxicol. Rev. 2005, 24, 271-278. [CrossRef] [PubMed]

9. Food and Agricultural Organization of the United Nations. Pesticides: Balancing Crop Protection and Responsible Use; Plant Production and Protection Division: Rome, Italy, 2014.

10. Matthews, G. Attitudes and behaviors regarding use of crop protection products-A survey of more than 8500 smallholders in 26 countries. Crop Prot. 2008, 27, 834-846. [CrossRef]

11. Atreya, K.; Johnse, F.H.; Sitaula, B.K. Health and environmental costs of pesticide use in vegetable farming in Nepal. Environ. Dev. Sustain. 2012, 14, 477-493. [CrossRef]

12. Karunamoorthi, K.; Mohammed, M.; Wassie, F. Knowledge and practices of farmers with reference to pesticide management: Implications on human health. Arch. Environ. Occup. Health 2012, 67, 109-116. [CrossRef] [PubMed]

13. Damalas, C.A.; Hashemi, S.M. Pesticide risk perception and use of personal protective equipment among young and old cotton growers in Northern Greece. Agrociencia 2010, 44, 363-371.

14. Blanco-Muñoz, J.; Lacasaña, M. Practices in pesticide handling and the use of personal protective equipment in Mexican agricultural workers. J. Agromed. 2011, 16, 117-126. [CrossRef] [PubMed]

15. Al-Ali, E.H.M.; Al-Hashash, H.K.; Al-Ageel, H.A.; Ben-Hejji, A.H. Multiple important plant viruses are present on vegetable crops in Kuwait. J. Clin. Trials 2013, 3, 136-139. [CrossRef] 
16. Bashour, I. Pesticides, fertilizers and Food Safety. In Arab Environment Future Challenges; Tolba, M.K., Saab, N.W., Eds.; Arab Forum for Environment and Development: Beirut, Lebanon, 2008; pp. 137-145.

17. Jallow, M.F.A.; Awadh, D.G.; Albaho, M.S.; Devi, V.Y.; Thomas, B.M. Pesticide risk behaviors and factors influencing pesticide use among farmers in Kuwait. Sci. Total Environ. 2017, 574, 490-498. [CrossRef] [PubMed]

18. El-Desouky, M.A.; Hassan, R.Z.; El-Enany, F.F. Exposure to pesticides in Kuwait. J. Kuwait Med. Assoc. 1978, 12, 215-227.

19. Al-Shatti, A.K.S.; El-Desouky, M.; Zaki, R.; Al-Azem, M.B.; Al-lagani, M. Health care for pesticides applicators in a locust eradication campaign in Kuwait (1988-1989). Environ. Res. 1997, 73, 219-226. [CrossRef] [PubMed]

20. Abahussain, E.A.; Ball, D.E. Pharmaceutical and chemical pediatric poisoning in Kuwait: A retrospective survey. Pharm. Pract. (Granada) 2010, 8, 43-49. [CrossRef] [PubMed]

21. Saeed, T.; Sawaya, W.N.; Ahmad, N.; Rajagopal, S.; Al-Omair, A.; Al-Awadhi, S. Chlorinated pesticides residues in the total diet of Kuwait. Food Control 2001, 12, 91-98. [CrossRef]

22. Saeed, T.; Sawaya, W.N.; Ahmad, N.; Rajgopal, S.; Al-Omair, A. Organophosphorus pesticide residue in the total diet of Kuwait. Arabian J. Sci. Eng. 2005, 30, 17-27.

23. Bu-Abbas, A.H.; Abdel-Satar, A.; Badawi, B.S.; Sanab, H.F. Contamination of the organophosphorus insecticide ethion residues in commercial samples of red-hot chilli spice in Kuwait. Int. J. Food Saf. Nutr. Public Health 2009, 2, 59-68. [CrossRef]

24. Hajjar, M.J. The persisted organic pesticides pollutant (POPs) in the Middle East Arab countries. Int. J. Agron. Plant Prod. 2012, 3, 11-18.

25. Saeed, T.; Sawaya, W.; Ahmad, N.; Rajagopal, S.; Dashti, B.; Al-Awadhi, S. Assessment of the levels of chlorinated pesticides in breast milk in Kuwait. J. Food Addit. Contam. 2000, 12, 1013-1018. [CrossRef] [PubMed]

26. Kish, L. Survey Sampling; John Wiley \& Sons Publishers: New York, NY, USA, 1965.

27. Kuwait Agricultural Statistics. A Survey on Behalf of Kuwait Central Statistics Bureau, Safat, Kuwait. 2013-2014. Available online: http://www.csb.gov.kw/Socan_Statistic_EN.aspx?ID=42 (accessed on 16 December 2016).

28. Agresti, A. An Introduction to Categorical Data analysis; John Wiley \& Sons Publishers: New York, NY, USA, 2007.

29. Jones, E.; Mabota, A.; Larson, D.W. Farmers' knowledge of health risks and protective gear associated with pesticide use on cotton in Mozambique. J. Dev. Areas 2009, 42, 267-282. [CrossRef]

30. Al-Zadjali, S.; Morse, S.; Chenoweth, J.; Deadman, M. Personal safety issues related to the use of pesticides in agricultural production in Al-Batinah region of Northern Oman. Sci. Total Environ. 2015, 502, 457-461. [CrossRef] [PubMed]

31. Mekonnen, Y.; Agonafir, T. Pesticide sprayers' knowledge, attitude and practice of pesticides use on agricultural farms in Ethiopia. Occup. Med. 2002, 52, 311-315. [CrossRef]

32. Hashemi, S.M.; Rostami, R.; Hashemi, M.K.; Damalas, C.A. Pesticide use and risk perceptions among farmers in southwest Iran. Hum. Ecol. Risk Assess. 2012, 18, 456-470. [CrossRef]

33. Osborne, P.P.; Xu, Z.C.; Swanson, K.D.; Walker, T.; Farmer, D.K. Dicamba and 2,4-D residues following applicator cleanout: A potential point source to the environment and worker exposure. J. Air Waste Manag. Assoc. 2015, 65, 1153-1158. [CrossRef] [PubMed]

34. Dalvie, M.A.; Africa, A.; London, L. Disposal of unwanted pesticides in Stellenbosch, South Africa. Sci. Total Environ. 2006, 361, 8-17. [CrossRef] [PubMed]

35. Keifer, M.C. Effectiveness of interventions in reducing pesticide overexposure and poisonings. Am. J. Prev. Med. 2000, 18, 80-89. [CrossRef]

36. Hogstedt, C.; Partanen, T.; McConnell, R.; Wesseling, C. Agricultural pesticide use in developing countries: Health effects and research needs. Int. J. Health Serv. 1997, 27, 273-308.

37. Droogers, P.; Immerzeel, W.W.; Terink, W.; Hoogeveen, J.; Bierkens, M.F.P.; Van-Beek, L.P.H.; Debele, B. Water resources trends in Middle East and North Africa towards 2050. Hydrol. Earth Syst. Sci. 2012, 16, 3101-3114. [CrossRef]

38. Staiff, D.C.; Davis, J.F.; Stevens, E.R. Evaluation of various clothing materials for protection and worker acceptability during application of pesticides. Arch. Environ. Contam. Toxicol. 1982, 11, 391-398. [CrossRef] [PubMed] 
39. Hwang, S.A.; Gomez, M.I.; Stark, A.D.; St. John, T.L.; Pantea, C.I.; Hallman, E.M.; May, J.J.; Scofield, S.M. Safety awareness among New York farmers. Am. J. Ind. Med. 2000, 38, 71-81. [CrossRef]

40. Weinberger, K.; Srinivasan, R. Farmers' management of cabbage and cauliflower pests in India and their approaches to crop protection. J. Asia Pac. Entomol. 2009, 12, 253-259. [CrossRef]

41. Chen, S.; He, F.; Zhang, Z.; Gao, Y.; Zhou, A.; Xie, C.; Xiong, L.; Chen, D.; Wang, S.; Jia, J. Evaluation of a safety educational programme for the prevention of pesticide poisoning. Med. Lav. 1998, 89, 91-98.

42. Rios-Gonzalez, A.; Jansen, K.; Sanchez-Perez, H.J. Pesticide risk perceptions and the differences between farmers and extensionists: Towards a knowledge-in-context model. Environ. Res. 2013, 124, 43-53. [CrossRef] [PubMed]

43. Rother, H.A. South African farm workers' interpretation of risk assessment data expressed as pictograms on pesticide labels. Environ. Res. 2008, 108, 419-427. [CrossRef] [PubMed]

44. Alam, A.; Wolff, H. Do pesticide sellers make farmers sick? Health, information sources and adoption of technology in Bangladesh. J. Agric. Resour. Econ. 2016, 41, 62-80.

45. Jin, S.; Bluemling, B.; Mol, A.P.J. Information, trust and pesticide overuse: Interaction between retailers and cotton farmers in China. NJAS Wageningen J. Life Sci. 2015, 72-73, 23-32. [CrossRef]

46. Lekei, E.E.; Ngowi, A.V.; London, L. Pesticide retailers' knowledge and handling practices in selected towns of Tanzania. Environ. Health 2014, 13, 79-87. [CrossRef] [PubMed]

47. Jaga, K.; Dharmani, C. Sources of exposure to and public health implications of organophosphate pesticides. Pan. Am. J. Public Health 2003, 14, 171-185. [CrossRef]

48. Weinstein, N.D.; Klein, W.M. Unrealistic optimism: Present and future. J. Soc. Clin. Psychol. 1996, 15, 1-8. [CrossRef]

(C) 2017 by the authors. Licensee MDPI, Basel, Switzerland. This article is an open access article distributed under the terms and conditions of the Creative Commons Attribution (CC BY) license (http:/ / creativecommons.org/licenses/by/4.0/). 